\title{
PERANCANGAN SISTEM INFORMASI MANAJEMEN ASET STMIK STIKOM INDONESIA
}

\author{
I Wayan Sudiarsa ${ }^{1)}$ Anak Agung Gede Bagus Ariana ${ }^{2)}$ \\ Prodi Sistem Komputer, STMIK STIKOM Indonesia, Denpasar, Bali ${ }^{1{ }^{12}}$ ) \\ sudiarsa@stiki-indonesia.ac.id ${ }^{1)}$ gungariana@stiki-indonesia.ac.id ${ }^{2)}$
}

\begin{abstract}
STMIK STIKOM Indonesia electronic assets was part off fixed asset that have a long life time. In this case asset was a non saleable stuff for operational needs. STTMIKSTIKOM Indonesia assets such as laboratory equipment that contain computer laboratory, computer network laboratory, graphical design and photography laboratory. STMIK STIKOM Indonesia assets is increasing Every year since 2008 . It needs a good administration rules for filing and counting depreciation of every assets. It is important to have such a system starting from procurement, updating data and asset extermination. According to asset management research by sudrajat, 2007, asset management profit have relation to accountability, service management, risk management, and finance efficiency. (1) Improve management and accountability by showing to owners, users and stakeholders that the result is an effective and efficient service. (2) Provide a basis for evaluation and balancing of services, pricing and quality. (3) Increased accountability for resource use by performance and financial accounting. (4) Improving communications and relationships with users, improving understanding of service needs and options, formal consultation or agreement with users about service levels, a comprehensive approach of asset management within organizations with teams from multidisciplinary management. 5. Improve customer convenience and corporate image. Based on the exposure of problems and expected goals, it conducted research on asset management information system on STMIK STIKOM Indonesia.
\end{abstract}

Keywords : asset management, information system.

\begin{abstract}
ABSTRAK
STMIK STIKOM Indonesia memiliki aset barang elektronik yang merupakan bagian dari aktiva tetap dengan jangka waktu penggunaan yang cukup lama. Aset dalam hal ini merupakan benda yang tidak dijual kembali untuk kegiatan operasional. Aset pada STMIK STIKOM Indonesia seperti peralatan laboratorium yang mencakup laboratorium komputer, laboratorium jaringan komputer, laboratorium desain dan fotografi. Sejak berdiri tahun 2008 saat ini jumlah aset yang dimiliki STMIK STIKOM Indonesia semakin meningkat. Diperlukan suatu tertib administrasi pencatatan dan penghitungan penyusutan masing-masing aset. Hal ini diperlukan untuk membangun pengelolaan aset dimulai dari pengadaan, perubahan data dan penghapusan aset. Menurut penelitian tentang manajemen aset (Sudrajat, 2007), keuntungan dari manajemen aset berhubungan dengan akuntabilitas, manajemen layanan, manajemen resiko dan efisiensi keuangan. (1) Meningkatkan pengurusan dan akuntabilitas dengan menunjukkan ke pemilik, pengguna dan pihak yang terkait bahwa layanan yang dihasilkan adalah layanan yang efektif dan efisien. (2) Menyediakan dasar untuk evaluasi dan penyeimbangan layanan, harga dan kualitas. (3) Peningkatan akuntabilitas untuk penggunaan sumber daya dengan penghitungan kinerja dan keuangan. (4) Meningkatkan komunikasi dan hubungan dengan pengguna layanan dengan, meningkatkan pengertian pada kebutuhan layanan dan pilihan-pilhannya, konsultasi formal atau persetujuan dengan pengguna tentang level layanan, pendekatan yang menyeluruh dari manajemen aset di dalam organisasi dengan team yang berasal dari multi disiplin manajemen. 5. Meningkatkan kenyamanan pelanggan dan citra perusahaan. Berdasarkan pemaparan permasalahan serta tujuan yang diharapkan, maka dilakukan penelitan mengenai sistem informasi manajemen aset pada STMIK STIKOM Indonesia.
\end{abstract}

Kata kunci: Sistem Informasi, Manajemen Aset 


\section{PENDAHULUAN}

Aset barang elektronik adalah merupakan bagian dari aktiva tetap yang mana memiliki jangka waktu yang lama, digunakan dalam kegiatan perusahaan, dimiliki untuk tidak dijual kembali dalam kegiatan normal perusahaan serta memiliki nilai yang cukup besar (Soemarso,1992). Sistem Informasi Manajemen Aset digunakan untuk pengelolaan aset / inventori. Implementasi sistem informasi manajemen aset pada hakekatnya adalah upaya untuk tertib dokumen dan tertib administrasi pengelolaan aset. Tertib dokumen aset berkaitan dengan upaya penyediaan dan pendataan data/dokumen yang menyertai keberadaan aset, sedangkan tertib administrasi lebih dimaksudkan pada upaya membangun prosedur pengelolaan aset mulai saat pengadaan, perubahan data, hingga penghapusan aset (Hartono, 2010).

Berdasarkan hasil diskusi dengan pihak-pihak yang terkait dengan pengelolaan inventaris yaitu bagian umum dan jajaran pembantu ketua II, belum terdapat sistem yang menangani pengelolaan aset elektronik pada STMIK STIKOM Indonesia. Sistem yang ada saat ini hanya mencakup proses pengadaan barang inventaris. Proses penghitungan penyusutan aset elektronis belum terkelola dengan baik.

Permasalahan yang terjadi adalah sulit mendeteksi aset-aset elektronik yang memiliki umur ekonomis yang telah lewat. Beberapa aset elektronik sering mengalami pemindahan lokasi dari suatu laboratorium ke bagian yang lain. Permasalahan selanjutnya terkait dengan penggunaan sumber daya listrik yang berkaitan dengan biaya dan daya listrik yang dimiliki STMIK STIKOM Indonesia. Strategi pemeliharaan juga sangat diperlukan jika terdapat laporan yang jelas mengenai kondisi inventaris atau aset elektronik.

Berdasarkan pemaparan diatas maka dilaksanakan penelitian dengan tujuan merancang dan membangun sistem informasi manajemen aset di STMIK STIKOM Indonesia.

\section{TINJAUAN PUSTAKA}

\section{Aktiva}

Ikatan Akuntansi Indonesia (2009) mengungkapkan, aktiva adalah sumber daya yang dikuasai entitas sebagai akibat dari peristiwa masa lalu dan dari mana manfaat ekonomi di masa depan diharapkan akan diperoleh entitas. Manfaat ekonomi masa depan yang terwujud dalam aset tersebut untuk memberikan sumbangan, baik langsung maupun tidak langsung, terhadap aliran kas dan setara kas kepada entitas.

\section{Aktiva Tetap}

Menurut Soemarso (1992), aktiva tetap adalah aktiva yang (1) jangka waktu pemakaiannya lama; (2) digunakan dalam kegiatan perusahaan; (3) dimiliki untuk tidak dijual kembali dalam kegiatan normal perusahaan serta; (4) nilainya cukup besar. Menurut Waluyo (2010) aktiva tetap adalah bagian dari neraca yang dilaporkan oleh manajemen dalam setiap periode atau setiap tahun. Aktiva ini digolongkan menjadi aktiva tetap berwujud dan aktiva tetap tidak berwujud. Penggolongan semacam ini dikemukakan oleh Smith dan Skousen (1989), adalah sebagai berikut:

1. Aktiva tetap yang berwujud (tangible fixed assets) Merupakan harta berwujud yang bersifat jangka panjang dalam aktivitas operasi perusahaan, didalamnya meliputi; tanah, bangunan, perabot, mesin-mesin, dan peralatan lain yang digunakan untuk menghasilkan atau memudahkan penjualan barang dan jasa.

2. Aktiva tetap tidak berwujud (intangible fixed assets) Tidak dapat diobservasi atau dilihat secara langsung, didalamnya berbentuk persetujuan, kontrak, atau paten, tetapi harta itu sendiri tidak memiliki eksistensi fisik. Harta tak berwujud termasuk pos-pos seperti hak cipta, paten, goodwill, dan perjanjian monopoli.

\section{Penyusutan}

Soemarso (1992) mengungkapkan, semua jenis aktiva tetap kecuali tanah, akan makin berkurang kemampuannya untuk memberikan jasa bersamaan dengan berlalunya waktu. Beberapa faktor yang mempengaruhi menurunnya kemampuan adalah pemakaian, keausan, ketidakseimbangan kapasitas yang tersedia dengan yang diminta dan keterbelakangan teknologi. Berkurangnya kapasitas berarti berkurangnya nilai aktiva tetap yang bersangkutan. Hal seperti ini perlu dicatat dan dilaporkan. Pengakuan adanya penurunan nilai aktiva tetap berwujud disebut penyusutan (depreciation). 


\section{Manajemen Asset}

Menurut penelitian tentang manajemen aset (The Institute of Asset Management, 2010), pengelolaan dari aset fisik (mulai dari pemilihan, pemeliharaan, inspeksi dan pembaharuan) yang memainkan peran penting dalam menentukan kinerja operasional dan profitabilitas industri yang mengoperasikan aset sebagai bagian inti dari proses bisnis. Sedangkan menurut Suhairi (2010), siklus manajemen aset mempertimbangkan semua pilihan dan strategi manajemen sebagai bagian dari aset masa pakai, dari perencanaan sampai penghapusan aset. Tujuan adalah untuk mencari biaya terendah dalam jangka panjang (bukan penghematan dalam jangka pendek) ketika membuat keputusan dalam aset manajemen.

\section{METODE PENELITIAN}

\section{Sumber Data}

Data yang digunakan sebagai sumber dalam penelitian ini berupa kartu inventaris barang, list aset perusahaan, kartu pemeliharaan barang serta keterangan-keterangan yang diberikan oleh orang yang terkait dengan sistem. Data ini kemudian disusun dan diolah agar dapat dipakai sebagai acuan dalam menyusun penelitian ini.

\section{Metode Pengumpulan Data}

Metode yang digunakan untuk melakukan pengumpulan data dalam menyusun penelitian ini adalah : Metode Observasi dan Metode Studi Literatur

\section{Metode Penelitian}

Setelah melakukan pengumpulan data dan informasi untuk menunjang pembangunan sistem, selanjutnya penelitian dilanjutkan dengan beberapa tahapan pada Gambar (1), yaitu:

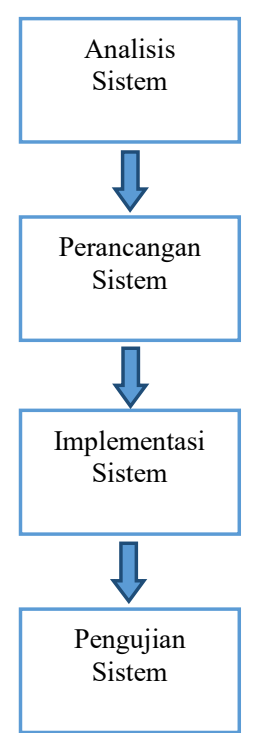

\section{Gambar1. Metode Penelitian}

(1)Analisa kebutuhan dilakukan untuk mengetahui kebutuhan data, proses yang terlibat dalam sistem yang dibangun, serta hubungan antar suatu proses dengan proses lainnya. Hasil analisa kebutuhan ini selanjutnya akan digunakan utuk proses perancangan aplikasi.

(2)Perancangan Sistem, Tahapan pada perancangan aplikasi meliputi pembuatan diagram alir data, rancangan basis data, dan rancangan antarmuka. Sistem akan dibangun berbasis web untuk memenuhi akses data yang dibutuhkan saat proses perwalian tanpa perlu melakukan instalasi sebelumnya.

(3)Implementasi Sistem, Adapun alat-alat yang dipergunakan dalam perancangan media pembelajaran ini terdiri dari 2 bagian utama, yaitu; Perangkat lunak

Adapun perangkat lunak yang digunakan untuk membuat sistem informasi monitoring ini, terdiri dari : Sistem Operasi Windows 7 home premium, MySQL, PHP, Framework Laravel 5.3,

Perangkat keras

Peralatan perangkat keras yang digunakan untuk membuat sistem informasi monitoring ini, terdiri dari : Komputer dengan processor Intel Core i3 CPU $2.13 \mathrm{GHz}$, RAM 4 GB, Harddisk IDE 250 GB Seagate 7200rpm, VGA Nvidia GeForce 310M.

(4)Pengujian Aplikasi, Setelah melalui tahap perancangan aplikasi maka akan dilanjutkan dengan pembangunan berdasarkan data serta hasil yang diperoleh dari perancangan tersebut. 
Aplikasi yang telah selesai dibangun akan melalui tahap pengujian untuk memastikan aplikasi telah memenuhi kebutuhan. Aplikasi yang telah teruji ini akan diimplementasikan di STMIK STIKOM Indonesia.

\section{HASIL DAN PEMBAHASAN Analisis Sistem}

Berdasarkan hasil observasi pada proses manajemen aset di STMIK STIKOM Indonesia, diperlukan sebuah sistem informasi yang dapat membantu untuk melakukan proses pengelolaan aset. Sistem yang dibangun diharapkan dapat membantu dalam proses analisis kebutuhan terhadap belanja aset serta untuk monitor pemeliharaan aset. User admin terlebih dahulu melakukan perekaman terhadap seluruh data aset yang ada di STMIK STIKOM Indonesia. Proses perekaman awal dilakukan dengan memasukkan data nilai perolehan aset saat ini, serta tahun aset diadakan. Aset dibagi menjadi beberapa kategori aset seperti: (1) Gedung, (2) Ruangan, (3) Aset Elektronik, (4) Aset Furniture dan (5) Kendaraan. Masing-masing aset memiliki detail kategori, misalnya pada aset ruangan memiliki detail panjang, lebar dan tinggi ruangan. Pada aset elektronik memiliki detail seperti merek, daya listrik, umur pakai dan history perawatan. Pada masing-masing aset terdapat detail umur ekonomis aset. Proses terakhir adalah penghapusan aset beserta dengan alasan penghapusan aset. Untuk mempermudal melakukan proses monitoring, maka tiap aset memiliki detail ruangan tempat aset berada.

\section{Perancangan Sistem}

Rancangan Bangun Sistem Informasi Manajemen Aset dilakukan melalui beberapa tahapan mulai pemodelan sistem dengan menggunakan Data Flow Diagram untuk melihat skema aliran data dan Entity Relatioship Diagram (ERD) untuk pemodelan perancangan basis data.

Data Flow Diagram pada Gambar 2 menggambarkan proses utama yang merupakan hasil dari analisis kebutuhan fungsional sistem. Proses pertama adalah proses login yang dilakukan oleh admin sistem. Proses kedua adalah proses perekaman aset. Pada proses perekaman aset terdapat beberapa sub proses, antara lain: perekaman data kategori, perekaman master aset dan perekaman detail aset. Proses ketiga adalah pemeliharaan aset. Pada proses ini dilakukan perekaman data jika aset dipelihara. Record pemeliharaan ini akan tersimpan pada history perawatan. Proses keempat adalah proses penghapusan aset atau aset disposal. Data aset tidak dihapus dari sistem, hanya ditandai kondisi terakhir saat aset dimusnahkan, misalnya dijual, disumbangkan atau dimusnahkan. Proses terakhir adalah proses penyajian data pada menu dashboard sistem. Informasi yang disajikan pada dashboard merupakan intisari atau rangkuman data dari aset. Seperti total jumlah aset, total nilai aset dan list aset yang sudah dilakukan proses pemeliharan maupun yang belum.

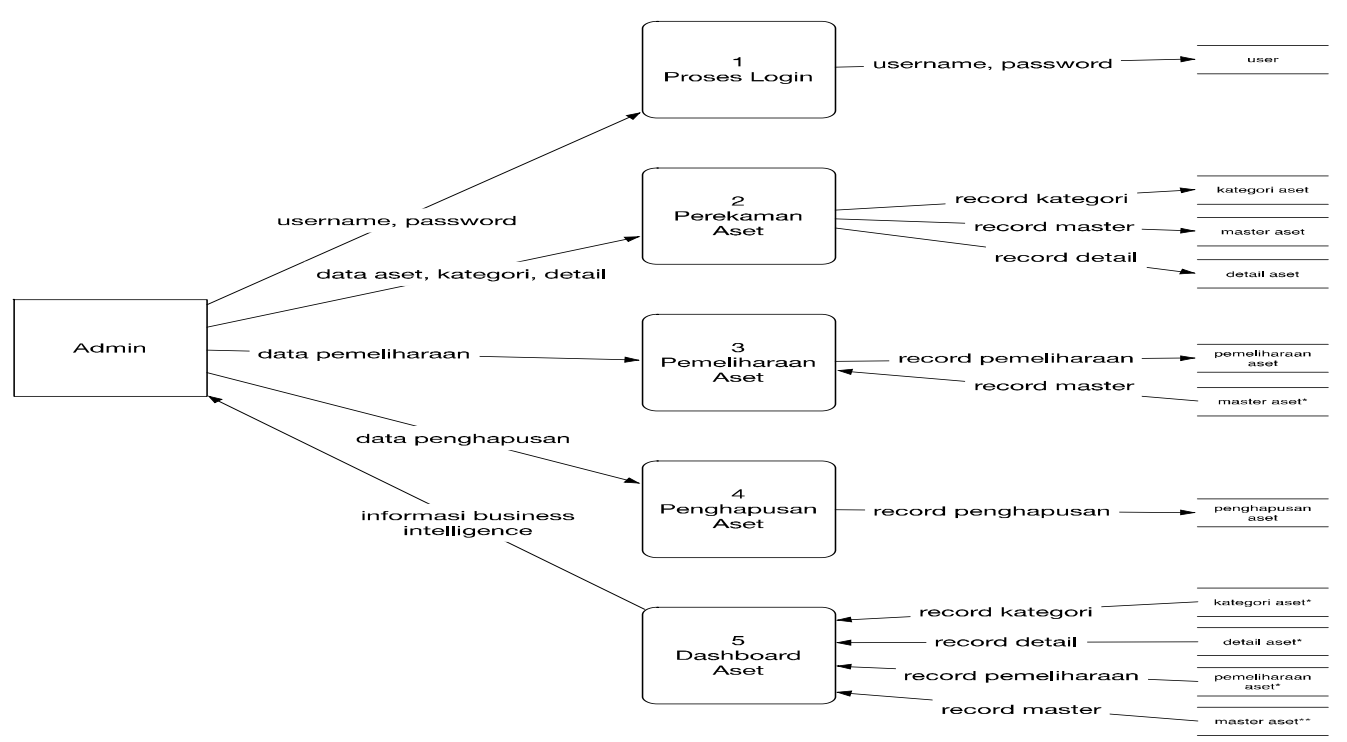

Gambar 2. Data Flow Diagram 
Pada Entity Relationship Diagram di Gambar 3 Terdapat empat entitas yaitu: (1) Kategori aset, (2) Master aset, (3) Detail aset dan (4) Pemeliharaan. Entitas katergori memiliki atribut idkategori, nama kategori dan status, entitas master aset memiliki atribut idmaster, idkategori, nama aset, nilai perolehan, tahun dan idruangan. Entitas detail aset memiliki atribut iddetil, idmaster, spesifikasi dan nilai. Sedangkan entitas pemeliharaan memiliki atribut idpemeliharaan, tanggal, remark dan biaya. Adapun kardinalitas masing-masing entitas adalah sebagai berikut:

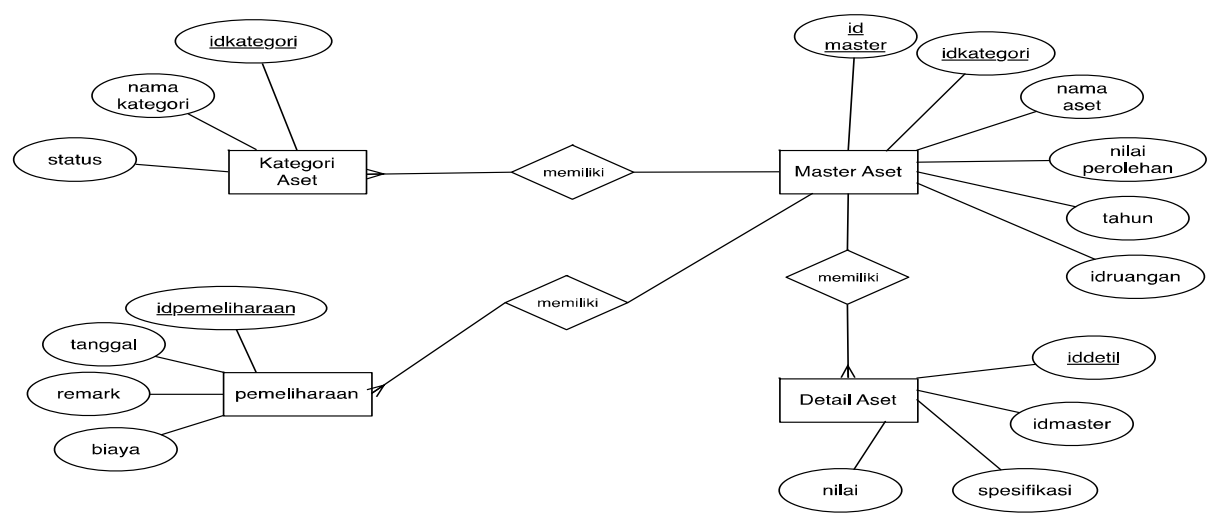

Gambar 3. Entity Relationship Diagram

\section{Implementasi Sistem}

Berikut merupakan hasil implementasi dari rancangan antarmuka yang telah dibahas sebelumnya:

Halaman login pada Gambar 4 telah dilengkapi dengan fasilitas hak akses, adapun hak akses antara lain: root atau super user, dan teknisi. Proses untuk penambahan user hanya dapat dilakukan oleh user root.

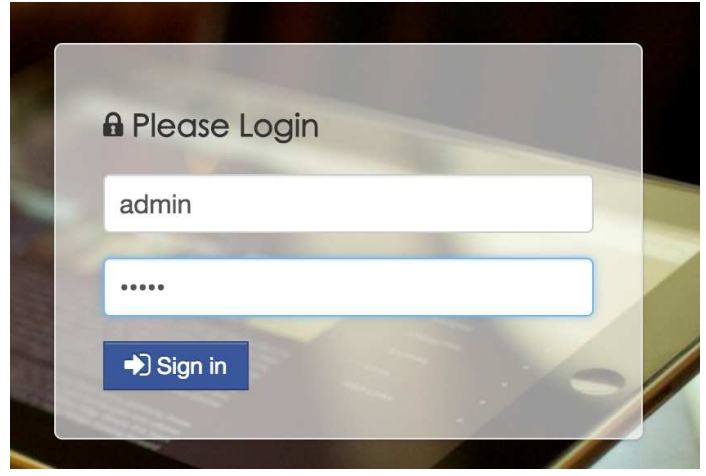

Gambar 4 Halaman Login

Setelah login maka user akan masuk ke halaman dashboard pada Gambar 5. Pada halaman ini akan terlihat ringkasan informasi yang diperlukan oleh pengguna. Antara lain: data total aset, aset baru, aset rusak, asek yang diperbaiki, total lokasi aset dan laporan aset. 


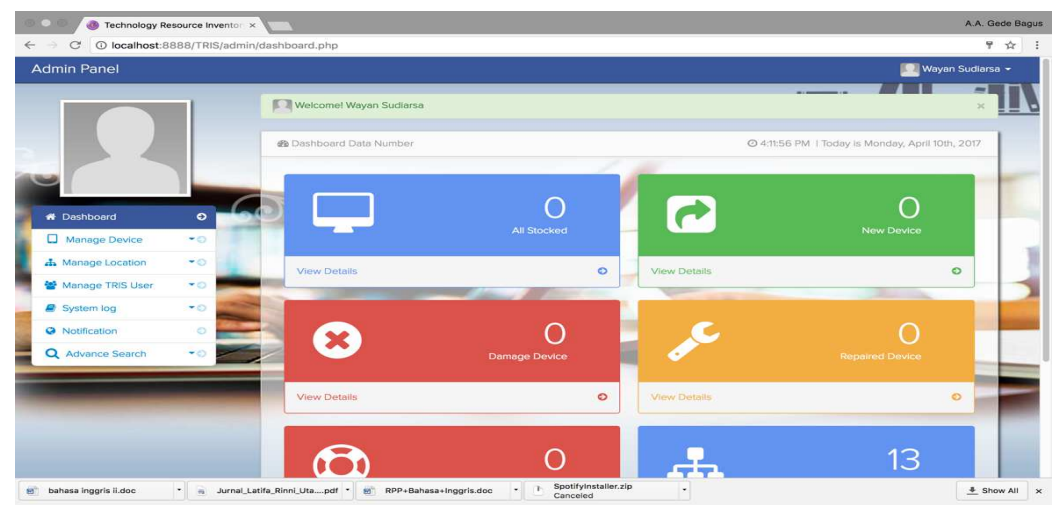

Gambar 5. Halaman Dashboard

Pada halaman manajemen aset Gambar 6, pengguna dapat melakukan proses pencetakan dan penambahan aset. Apapun isian data yang ada pada halaman manajemen aset antara lain nama aset/alat, deskripsi aset, kode aset, merek aset, model alat dan status aset. Halaman dilengkapi dengan pagging yang memudahkan penggunakan melakukan navigasi pada halaman. Pada sebelah kiri halaman terdapat menu yang bisa diakses oleh pengguna. Menu yang ada anatara lain: manajemen aset, manajemen lokasi aset, manajemen pengguna, log sistem dan pencarian aset.

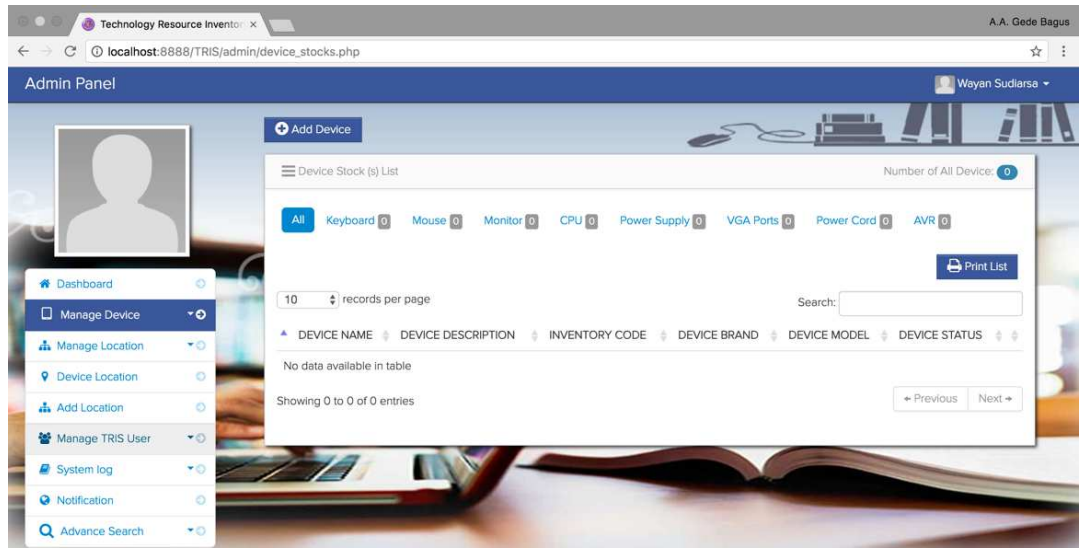

Gambar 6. Manajemen Aset

\section{Pengujian Sistem}

Untuk memastikan sistem yang dibangun telah berjalan dengan baik, maka dilakukan pengujian degan metode black box. Adapun bagian uji yang dilakukan sebagai berikut:

(1) Halaman Login. Pengujian dilakukan untuk memasikan halaman login dapat diakses dan berjalan dengan baik. Simulasi dilakukan dengan mencoba memasukkan username dan password dengan beberapa kondisi baik untuk kondisi berhasil login ataupun tidak berhasil login

(2) Halaman Data Aset. Pengujian dilakukan untuk melihat apakah data yang dimasukkan berhasil masuk ke tabel pada basis data. Simulasi dilakukan dengan memasukkan beberapa data aset. Pengujian dilakukan untuk memastikan penambahan data aset serta perubahan data dapat dilakukan dengan baik, sehingga jika ada beberapa field data yang bersifat mandatori belum terisi maka sistem akan menolak proses penambahan maupun perubahan data.

(3) Halaman Data Detail Kategori Aset. Pengujian selanjutnya adalah input detail kategori aset, pengujian dilakukan setelah ada aset berhasil disimpan. Pada halaman akan muncul opsi untuk memasukkan detail kategori aset. Sistem akan diuji pada beberapa kategori aset yang berbeda. Simulasi dilakukan untuk memastikan data detail kategori yang muncul sesuai dengan data yang telah ditentukan pada master data detail kategori. 
(4) Halaman Kelola Pemeliharaan Aset. Pengujian dilakukan untuk memastikan proses pengelolaan aset telah berjalan dengan baik. Pada sistem pengelolaan antara lain melakukan perubahan status aset dari baik menjadi rusak. Pengujian lain juga dilakukan untuk menguji penambahan jenis aset dapat dilakukan.

\section{SIMPULAN}

Berdasarkan hasil pengujian aplikasi yang telah dilakukan, maka dapat disimpulkan hal-hal sebagai berikut:

- Sistem informasi manajemen aset yang telah berhasil dibangun dengan menggunakna pendekatan perancangan Data Flow Diagram dan Entity Relational Diagram.

- Dengan menggunakan sistem berbasis web, mempermudah bagi pemegang kepentingan terhadap aset untuk mengakses sistem.

- Hasil pengujian dengan metode blackbox menghasilkan hasil yang sudah sesuai dengan kebutuhan sistem yang diminta

\section{DAFTAR PUSTAKA}

[1] Irwanto, D., 2006, Perancangan Object Oriented Software dengan UML, Andi, Yogyakarta.

[2] Kristanto, A., 2003, Perancangan Sistem Informasi dan Aplikasinya, Gava Media, Jakarta.

[3] Hartono. 2010, Sistem Informasi Manajemen Aset / Inventory / Logisitk. Diakses 10 April, 2016, dari Web Site Digital Sense :

http://www.digitalsense.net/sistem-informasimanajemenaset-inventori-logistik

[4] Ikatan Akuntansi Indonesia. 2009. Standar Akuntansi Keuangan Entitas tanpa Akuntanbilitas Publik. Jakarta: Dewan Standar Akuntansi Keuangan.

[5] S.R, Soemarso. 1992. Akuntansi Suatu Pengantar Buku 2 Edisi Keempat. Jakarta : Rineka Cipta.

[6] Sudrajat, Iwan. 2007, Landasan Teori Asset Management. Diakses 3 April, 2016, dari Web Site Manajemen Aset : http://assetmanagement.wordpress.com/ 2007/06/14/defintions/

[7] Suhairi. 2010. PERANCANGAN SISTEM INFORMASI MANAJEMEN ASET (STUDI KASUS PADA PT.CIPTAKRIDATAMA). Jakarta :

Universitas Gunadarma 